Final version:

Du, S., Swaen, V., Lindgreen, A., and Sen, S. (2013), "The roles of leadership styles in corporate social responsibility", Journal of Business Ethics, Vol. 114, No. 1, pp. 155-169. (ISSN 01674544)

For full article, please contact LindgreenA@cardiff.ac.uk

The Roles of Leadership Styles in Corporate Social Responsibility

\author{
SHUILI DU ${ }^{1}$ \\ Simmons School of Management \\ VALÉRIE SWAEN ${ }^{2}$ \\ Université catholique de Louvain \\ ADAM LINDGREEN ${ }^{3}$ \\ University of Cardiff \\ SANKAR SEN ${ }^{4}$ \\ City University of New York
}

Topic section: Leadership

\footnotetext{
${ }^{1}$ Shuili Du, Simmons School of Management, 300 Fenway, Boston, MA 02115, United States. E-mail: shuili.du@simmons.edu.

${ }^{2}$ Valérie Swaen, Université catholique de Louvain, Louvain School of Management, Place des Doyens 1, 1348 Louvain-la-Neuve, Belgium and IESEG School of Management, 3 rue de la Digue, 59800 Lille, France. E-mail: valerie.swaen@uclouvain.be.

${ }^{3}$ Adam Lindgreen, Department of Marketing, Cardiff Business School, University of Cardiff, Aberconway Building, Colum Drive, Cardiff CF10 3EU, United Kingdom. E-mail: lindgreena@cardiff.ac.uk.

${ }^{4}$ Sankar Sen, Department of Marketing \& International Business, Zicklin School of Business, Baruch College/City University of New York, One Bernard Baruch Way, Box B12-240, New York, NY 10010, United States. E-mail: sankar.sen@baruch.cuny.edu.
} 
ABSTRACT. This research investigates the interplay between leadership styles and institutional corporate social responsibility (CSR) practices. A large-scale field survey of managers reveals that firms with greater transformational leadership are more likely to engage in institutional CSR practices, whereas transactional leadership is not associated with such practices. Furthermore, stakeholder-oriented marketing reinforces the positive link between transformational leadership and institutional CSR practices. Finally, transactional leadership enhances, whereas transformational leadership diminishes, the positive relationship between institutional CSR practices and organizational outcomes. This research highlights the differential roles that transformational and transactional leadership styles play for a firm's institutional CSR practices and has significant implications for theory and practice.

KEY WORDS: corporate social responsibility, transformational leadership, transactional leadership, stakeholder-oriented marketing, organizational outcomes. 
Corporate social responsibility (CSR), defined as "the broad array of strategies and operating practices that a company develops in its efforts to deal with and create relationships with its numerous stakeholders and the natural environment" (Waddock, 2004, p. 10), has moved from ideology to reality. More than 6,000 corporations across 135 different countries have adopted the United Nation's Global Compact policy, committing to align their business operations with a set of standards of socially responsible behaviors. These widespread CSR efforts are driven not only by ideological thinking that firms can be positive forces for social change but also by the business returns that firms potentially reap from CSR engagement. Prior research has shown that CSR enables a firm to appeal to the socio-cultural norms of its institutional environment and contributes to its social legitimacy (Handelman and Arnold, 1999; Palazzo and Scherer, 2006; Scott, 1987). In turn, social legitimacy ensures the continuous flow of resources and sustained support from the firm's internal and external stakeholders (Palazzo and Scherer, 2006; Pfeffer and Salancik, 1978; Sen and Bhattacharya, 2001), which ultimately results in enhanced firm financial performance (Luo and Bhattacharya, 2006; Margolis and Walsh, 2003).

However, despite a growing body of research documenting the business case of CSR, our knowledge of organizational antecedents to CSR remains embryonic (Angus-Leppan et al., 2009). Leading scholars from various business disciplines (e.g., strategy, organizational behavior, marketing) have pointed out the dearth of research on external and internal institutional factors that might shape CSR activities in the first place and vigorously called for more research on its organizational antecedents (Campbell, 2007; Hoffman and Bazerman, 2007; Margolis and Walsh, 2003). In particular, considering the importance of leadership in shaping organizational strategies 
and practices, the lack of research on the interface between organizational leadership and CSR is noteworthy (Groves and LaRocca, 2011a; Waldman and Siegel, 2008).

Recent enthusiasm about the topic of responsible leadership (Maak and Pless, 2006; Pless and Maak, 2011) also highlights certain deficiencies in current leadership theories, particularly with regard to the interface between leadership and CSR. Responsible leadership theory broadens the notion of leadership from a traditional leader-subordinate relationship to leaderstakeholder relationships and contends that "building and cultivating ... ethically sound relations toward different stakeholders is an important responsibility of leaders in an interconnected stakeholder society" (Maak and Pless, 2006, p. 101). Reflecting the urgent need to bridge leadership theories and CSR literature, Waldman et al. (2006) call specifically for research that "consider[s] a broader array of leadership components and practices" (p. 1721), such as transformational and transactional leadership styles, as drivers of CSR practices. Relatedly, although different leadership styles have been linked to organizational effectiveness measures, such as employee satisfaction and financial performance (Lowe et al., 1996), no prior research has investigated how leadership styles influence the effectiveness of CSR in generating positive organizational outcomes.

This study addresses these research gaps by investigating how the leadership styles adopted by firm managers, specifically, transformational and transactional leadership, affect the firm's CSR practices and the organizational outcomes of CSR. This study contributes to the interface of organizational leadership and CSR in several significant ways. First, to the best of our knowledge, this large-scale field study is the first to investigate both transformational and transactional leadership styles exhibited by managers as potential antecedents of the firm's CSR practices. Waldman et al. (2006) find that one component of transformational leadership, 
intellectual stimulation, relates positively to CSR. However, they do not examine transactional leadership or other components of transformational leadership (e.g., charisma) as possible antecedents. Furthermore, they focus on CEO leadership, whereas this study considers leadership styles by management in general.

Second, going beyond a main effect model of the leadership-CSR relationship, we investigate how a firm's stakeholder-oriented marketing interacts with leadership styles to jointly influence the firm's CSR practices. We adopt a theoretical perspective that spans organizational behavior (i.e., leadership styles) and marketing (i.e., stakeholder-oriented marketing), because CSR is inherently a cross-disciplinary phenomenon (Du et al., 2011; Raghubir et al., 2010). By showing that stakeholder-oriented marketing reinforces the positive link between transformational leadership and a firm's CSR activities, this research paints a more nuanced and complex picture of organizational antecedents to CSR. Specifically, this research indicates that stakeholder-oriented marketing provides necessary cross-functional support (e.g., broader and deeper understanding of stakeholder needs) to catalyze the positive impact of transformational leadership on a firm's CSR practices. More generally, our research highlights the importance of cross-disciplinary investigations in CSR research.

Third, this study extends current knowledge about organizational factors that influence the business case of CSR. Prior literature has depicted a contingent picture of the organizational outcomes of CSR, including corporate reputation, competitive position, and the fit between CSR and core competences (Du et al., 2011; Porter and Kramer, 2011; Yoon et al., 2006). We extend this body of literature by showcasing that transformational and transactional leadership styles both moderate the organizational outcomes of CSR, but in opposite ways. Transactional leadership enhances, whereas transformational leadership diminishes, the positive relationship 
between CSR and organizational outcomes. This finding accentuates the unique strength of transactional leadership in deriving business benefits from CSR.

We structure the remainder of this article as follows. We first review relevant literature on CSR, leadership styles (transformational and transactional leadership), and stakeholderoriented marketing to derive our conceptual framework and a set of hypotheses. We then describe our methodology and present the results of a large-scale field survey that tests these hypotheses. We end with a discussion of theoretical and managerial implications, as well as limitations of our study and avenues for further research.

\section{Conceptual framework and hypotheses}

\section{Institutional CSR}

Corporate social responsibility activities are manifest in organizational programs that protect and improve societal welfare, ranging from cause-related marketing, employee benefits, community outreach, to eco-friendly or sustainable business practices. According to stakeholder theory (Freeman et al., 2007), a firm interacts with both primary stakeholders, who are essential to the operation of the business (i.e., customers, employees, and investors), and secondary stakeholders, who can influence the firm's business operation only indirectly (i.e., community and the natural environment; Waddock, 2008).

In line with stakeholder theory, prior CSR literature has differentiated between technical CSR — activities that target the firm's primary stakeholders - and institutional CSR — activities that target the firm's secondary stakeholders (Godfrey et al., 2009). Mattingly and Berman (2006) performed an exploratory factor analysis of the Kinder Lydenburg Domini (KLD) investment firm's social rating dataset, a widely used CSR data source and perhaps one of the most authoritative ones, and uncovered a pattern that differentiates between technical CSR and 
institutional CSR. Technical CSR mainly refers to a firm's CSR actions in product (i.e., customer), employee, and governance domains, such as actions to enhance product quality and safety, provide employee benefits (e.g., healthcare, work-life balance), and improve organizational governance (e.g., independent board members). Institutional CSR instead covers a firm's CSR activities in the community and environment domains, such as giving back to local communities (e.g., education, arts, culture) and incorporating environmental concerns in business decisions (e.g., clean technology, recycling).

We focus on institutional CSR activities for several reasons. First, they are prevalent and important. Corporate commitment to local communities is steadily increasing, despite the recent economic downturn (CorporatePhilanthropy, 2011). For example, Target Corporation, the second largest discount retailer in the United States, donates 5\% of its income (\$3 million per week) to communities where it operates, supporting public schools, disadvantaged children, and a wide range of programs in arts, culture, and health. More broadly, many Fortune 500 firms commit substantial resources to support local communities (CorporatePhilanthropy, 2011). Firms are also rapidly embracing environment-related CSR actions, as they seek to reduce their ecofootprint and engage in sustainable business practices (Waddock, 2008). Indeed, Hart (1997, p. 71) predicts, "sustainable development will constitute one of the biggest opportunities in the history of commerce."

Second, from a theoretical point of view, because primary stakeholders tend to have more power (utilitarian, coercive, or normative) in making legitimate and urgent claims on the firm, technical CSR activities are often of a reactive, "cost of doing business" nature. In contrast, because legitimate claims by secondary stakeholders often lack power or urgency (Mitchell et al., 1997), institutional CSR activities are more likely to result from discretionary decision making 
by organizational leaders. The linkages between leadership styles and institutional CSR thus warrant theoretical investigation.

Third, institutional CSR should generate more long-term organizational outcomes, such as positive image and stronger stakeholder relationships. Godfrey et al. (2009) argue that technical CSR activities are often perceived as self-serving and consistent with the firm's profitmaking interests, and therefore are more likely to produce short-term exchange capital rather than long-term moral capital or goodwill. In contrast, institutional CSR activities are likely to be viewed as voluntary acts of social beneficence, indicative of the firm's benevolent, otherregarding orientation. As such, institutional CSR is more likely to generate intangible values, such as positive corporate image.

\section{Leadership styles and institutional CSR}

Most leadership theories, such as leader-member exchange theory and individualized leadership models, focus on dyadic or small group phenomena, rather than leaders' influence over organizational processes (Waldman et al., 2006; Yukl, 1999). This research adopts the strategic leadership paradigm and focuses not on the leader-follower dyadic relationship but rather on how leaders, or managers, influence the firm's strategic processes, such as institutional CSR. In line with the conceptualization that leadership represents a shared or collective mental model (Bass, 1998; Basu and Palazzo, 2008), we look at leadership styles exhibited by managers throughout the firm, not just at the top level.

Burns (1978) has identified two leadership styles, transformational and transactional, that managers might exhibit. The transformational leader is one who articulates a vision of the future that can be shared with followers, intellectually stimulates followers, and pays attention to individual differences among employees. In contrast, the transactional leader motivates 
employees primarily through contingent-reward exchanges (Burns, 1978; Waldman et al., 1987). Although Burns (1978) originally represented transformational and transactional leadership styles as opposite ends of a continuum, subsequent research (e.g., Bass, 1985, 1998) conceptualizes them as distinct dimensions. Thus a manager may exhibit characteristics of both. Transactional leaders are more effective at operating an existing system; they set goals, articulate explicit agreements regarding expectations and rewards, and provide constructive feedback to keep everybody on task (Bass and Avolio, 1993; Vera and Crossan, 2004). Transformational leaders are more effective at driving change, or transcending the status quo; they inspire followers with their vision and create excitement through use of symbolism and imagery (Bass and Avolio, 1993). By questioning the tried and true, transformational leaders seek to reframe the future (Bass and Avolio, 1993).

A firm's institutional CSR addresses the needs of its secondary stakeholders and may be capable of building social legitimacy (Handelman and Arnold, 1999), moral capital (Godfrey et al., 2009), and long-term competitive advantage (Porter and Kramer, 2011). We expect transformational (but not transactional) leadership to inspire more institutional CSR practices, for several reasons. First, transformational leadership is associated with altruistic ethics, whereas transactional leadership is associated with utilitarian ethics (e.g., use of power, rewards, and sanctions; Groves and LaRocca, 2011b). According to Bass and Steidlmeier (1999), transformational leaders are highly ethical and focused on values. Mendonca (2001) argues that transformational leaders reach higher levels of moral development than transactional leaders and articulate a vision that is both just and in sync with the demands of various stakeholders, motivating followers to transcend their self-interest for the larger vision of the firm. Recent theoretical (Maak and Pless, 2006; Pless and Maak, 2011) and qualitative (Angus-Leppan et al., 
2010) studies also suggest that transformational leaders are likely to exhibit ethical, or responsible, leadership behaviors such as protecting and advancing the interests of secondary stakeholders.

Second, transformational leadership is intellectually stimulating and encourages followers to question old assumptions so they can approach complex problems and issues in more innovative ways (Bass, 1997). Waldman et al. (2006) argue that transformational leaders, particularly intellectually stimulating ones, scan and think broadly about the environmental context and the manner in which various organizational stakeholders may be served. These authors find that the intellectual stimulation factor of transformational leadership is positively associated with CSR practices. We argue in turn that transformational leaders are more likely to realize the complex interconnections among a firm's various stakeholders and view the firm as interdependent with, rather than isolated from, its community and natural environment. In other words, transformational leaders' broader view of the firm should stimulate organizational learning and foster institutional CSR practices that consider the needs and challenges of both primary and secondary stakeholders (Vera and Crossan, 2004). On the contrary, transactional leaders mostly focus on maintaining the status quo and only pay attention to constraints and efficiency. They likely subscribe to a narrow, predominantly shareholder-centric view of the firm and consider institutional CSR a distraction from the firm's core purpose of shareholder value maximization (Friedman, 1970). Overall, the preceding arguments indicate that firms with greater transformational leadership will have more institutional CSR practices.

H1: Transformational (but not transactional) leadership is positively associated with a firm's institutional CSR practices.

\section{Moderating role of stakeholder-oriented marketing}


Bass (1985) states that organizational characteristics influence the overall effectiveness of transformational leadership. Similarly, the strategic view of the firm emphasizes complementarities among key capabilities or behaviors (e.g., leadership capabilities, stakeholder orientation) that can give rise to synergy among complementary activities (Stieglitz and Heine, 2007; Teece et al., 1997). In the context of the transformational leadership-institutional CSR linkage, we expect stakeholder-oriented marketing to be a key factor that impacts the process by which transformational leadership inspires the design and implementation of a firm's institutional CSR. We focus on stakeholder-oriented marketing due to its practical significance, theoretical linkage to institutional CSR, and more importantly, its potential complementarity with transformational leadership. Theories of responsible leadership emphasize the importance of approaching leadership in the context of stakeholder theory (Bass and Steidlmeier, 1999; Pless and Maak, 2011). In the field of marketing, reflecting the paradigm shift from customerorientation to stakeholder-orientation (Ferrell et al., 2010), more and more firms are practicing stakeholder-oriented marketing, which goes beyond a narrow customer focus to address challenges involving multiple stakeholder groups, particularly with regard to local communities and the environment (Bhattacharya and Korschun, 2008; Lindgreen et al., 2009). Stakeholderoriented marketing, due to its more expansive perspective than the traditional customerorientation, makes organizational members continuously aware of and willing to act on various stakeholder issues. It also stimulates a general concern for not only primary stakeholders, but also secondary stakeholders, thus creating an organizational climate conducive to institutional CSR. Lindgreen et al. (2009) find that stakeholder-oriented marketing is positively associated with institutional CSR practices. 
We expect that stakeholder-oriented marketing reinforces the positive impact of transformational leadership on institutional CSR. As argued previously, transformational leaders often exhibit higher levels of ethical development, are more appreciative of the interdependence between the firm and its wide range of stakeholders, and challenge followers to formulate creative solutions to address the needs of all stakeholders. These leadership characteristics favor greater institutional CSR, though complementary activities and processes, such as stakeholderoriented marketing, will serve to catalyze the impact of transformational leadership on institutional CSR. As a critical organizational function, marketing plays an important role in facilitating CSR decision making by transformational leaders (Kotler and Lee, 2005). Consisting of both "outside-in" (e.g., environmental scanning, marketing research, understanding stakeholder needs) and "inside-out" (e.g., new product development, new service offerings introduced to the market, CSR campaigns) processes, stakeholder-oriented marketing enables a firm to better understand its environment and address its stakeholder-related challenges.

Specifically, through the broader environmental scanning necessitated by stakeholderoriented marketing, transformational leaders acquire deeper knowledge of the firm's stakeholders (e.g., community, environment) and key issues facing them. Furthermore, by providing essential cross-functional support (e.g., R\&D, public relations, community outreach), stakeholder-oriented marketing allows transformational leaders to forge strong stakeholder relationships and tap into the capabilities of secondary stakeholders (e.g., non-profit organizations) to deliver institutional CSR practices that cater to their needs (Kotler and Lee, 2005; Raghubir et al., 2010). In summary, we propose that stakeholder-oriented marketing consists of activities and processes that are complementary to transformational leadership for the design and implementation of institutional CSR practices. 
H2: Stakeholder-oriented marketing positively moderates the relationship between transformational leadership and institutional CSR practices. The relationship is more positive for firms practicing stakeholder-oriented marketing to a greater extent.

\section{Leadership styles and the organizational outcomes of institutional CSR}

In terms of the organizational outcomes of institutional CSR, prior research has shown that institutional CSR can generate various business benefits, such as stronger stakeholder relationships, a more positive corporate image, and goodwill (Bhattacharya et al., 2008; Du et al., 2011; Godfrey et al., 2009). The business impact of "doing good" hinges on a host of firm- and market-specific factors, such as firm expertise, reputation, and competitive positioning (Du et al., 2011; Godfrey et al., 2009; Luo and Bhattacharya, 2006, 2009). However, prior research has not attempted, either theoretically or empirically, to examine how leadership styles might affect the organizational outcomes of institutional CSR. We expect that transactional (but not transformational) leadership will amplify the positive impact of CSR on organizational outcomes for several reasons. First, societal impact, or the value provided to secondary stakeholders, is essential for institutional CSR to generate positive organizational outcomes (Bhattacharya et al., 2008; Du et al., 2008). Transactional leaders are more likely to apply a transactional, inputoutput mindset to the realm of institutional CSR and seek to maximize the societal impact at a given level of CSR commitment. These leaders, adept as they are at task implementation, set CSR-related goals, articulate explicit agreements regarding rewards to organizational members for their CSR pursuit, and provide constructive feedback to keep members on track throughout the execution of institutional CSR practices. Such active, transactional management of institutional CSR practices will likely enhance societal welfare. In turn, the greater societal impact of institutional CSR may lend credibility to the firm's CSR engagement, boosting its 
socially responsible image and strengthening its stakeholder relationships (Du et al., 2008;

Godfrey et al., 2009).

Second, the effective implementation of institutional CSR requires a firm to capitalize on its core business competence to effect positive change (Kotler and Lee, 2005; Porter and Kramer, 2006, 2011). Leadership literature suggests that though transformational leadership is better at competence exploration (e.g., acquiring entirely new knowledge and skills), transactional leadership is better at competence exploitation (e.g., refining and extending current knowledge and skills; March, 1991; Vera and Crossan 2004). Transactional leadership also emphasizes convergent thinking, efficiency, and continuity (Bass, 1985; Vera and Crossan, 2004). Accordingly, when implementing the firm's institutional CSR practices, transactional leaders should be more mindful of opportunities to leverage their business competence to maximize the social and business returns of institutional CSR. Close monitoring of task implementation and continuous improvement in the firm's institutional CSR practices, both characteristics of transactional leadership, also lead to more favorable organizational outcomes. We expect:

H3: Transactional (but not transformational) leadership positively moderates the relationship between institutional CSR practices and organizational outcomes. The relationship is more positive for firms with higher transactional leadership.

Our conceptual framework is represented in Figure 1.

Insert Figure 1 about Here

\section{Method}

Sample and procedures

We collected data in a nationwide, large-scale survey of managers of U.S. firms, whom we contacted through an independent marketing research firm, e-Rewards. This reputable, 
Dallas-based online sample provider has built its own consumer, business, and specialty panels with a total of 1.5 million members. The firm follows strict procedures to ensure the quality of its panels. For example, e-Rewards fully owns and controls the panels, which have not been merged or acquired from other firms; it verifies the physical existence of all panelists; and it limits participation by the average panelist to fewer than three full surveys per year. The firm also employs different methods to exclude professional survey takers.

Our sample covered a broad range of organizations in terms of type of business activities (business-to-business or business-to-consumer, physical goods or services), amount of sales revenues (from less than US\$10 million to more than US $\$ 1,000$ million), and number of employees (from less than 20 to more than 5,000). We screened respondents based on their functional roles to ensure that they are able to answer our survey questions as a result of their experience, knowledge of management policies, and access to organizational performance data. Most respondents held the following organizational positions: executives/owners, marketing/advertising personnel, general management, and administration. In addition, 94\% of them held middle- or upper-level management positions.

Qualified respondents were contacted via e-mail with an invitation to participate in an online survey, which would feature a lengthy questionnaire that included questions for the current study as well as another related study on CSR practices. Respondents were assured that their answers would be completely confidential and anonymous and that the analysis would take place at an aggregate level. Managers from 523 different U.S. organizations completed the survey. However, because preliminary tests showed that respondents would need at least 10 minutes to answer the survey, we excluded questionnaires from respondents who spent less than 10 minutes filling out the survey. We therefore retained 440 organizations in our study. In terms 
of organizational demographics, business-to-business and business-to-consumer organizations were roughly equally represented $(45.8 \%$ vs. $43.6 \%$, with the remaining $10.6 \%$ engaging in both). Organizations in our sample also varied substantially in size: $37.8 \%$ had fewer than 20 employees, $14.9 \%$ had 20-100 employees, $18.1 \%$ between 100 and 1,000 employees, and 29.1\% employed more than 1,000 people. In our analysis, we included organizational type (business-tobusiness vs. business-to-consumer) and size as covariates.

\section{Measures}

Transformational leadership. Transformational leadership was measured using items from Bass and Avolio (2000), according to three major dimensions (Bass, 1985; Waldman et al., 2006): (1) charisma (12 items) that "provides followers with a clear sense of purpose that is energizing, is a role model for ethical conduct and builds identification with the leader and his or her articulated vision" (Avolio et al., 1999, p. 444); (2) intellectual stimulation (4 items) that "gets followers to question the tried and true ways of solving problems, and encourages them to question the methods they use to improve upon them" (Avolio et al., 1999, p. 444); and (3) individualized consideration (4 items) that "focuses on understanding the needs of each follower and works continuously to get them to develop to their full potential" (Avolio et al., 1999, p. 444).

In our study, we only included items for charisma and intellectual stimulation as measures for transformational leadership. As stated previously, we adopt the strategic leadership approach and focus on how leadership influences strategic processes (i.e., institutional CSR practices); therefore, we excluded individualized consideration, which is mostly about dyadic leader-follower relationships. Because individualized consideration focuses on how a leader deals with individual followers in terms of mentoring, coaching, and individual development, it 
is not conceptually related to a firm's strategic decision making, such as the design and implementation of institutional CSR practices. According to Waldman et al. (2006, p. 1707), "because of the individual-level focus, a clear conceptual linkage with higher-level organizational phenomena, such as CSR, may be difficult to establish.” As is evident in our conceptualization, there is theoretical support for the hypothesized linkages between the other two aspects of transformational leadership (charisma and intellectual stimulation) and institutional CSR practices (e.g., Bass and Steidlmeier, 1999; Porter and Kramer, 2011; Vera and Crossan, 2004), but not much theoretical support linking individualized consideration to institutional CSR practices. For the purpose of this study, we excluded individualized consideration from our measure of transformational leadership.

The resulting 16 items measuring charisma and intellectual stimulation is highly reliable $($ Cronbach's alpha $=.96)$. We combined the two factors to form an overall measure of transformational leadership, consistent with prior research that has examined transformational leadership as a higher-order construct (e.g., Bass and Avolio, 2000; Bono and Judge, 2003; Walumbwa et al., 2008). Appendix 1 contains detailed information on the measures of transformational leadership and other key constructs.

Transactional leadership. Transactional leadership was also measured using items from Bass and Avolio (2000). Specifically, in line with prior literature (e.g., Derue et al., 2011; Lowe et al., 1996), we included (1) contingent rewards (4 items) that "clarifies what is expected from followers and what they will receive if they meet expected levels of performance" (Avolio et al., 1999, pp. 444-45) and (2) management by exception-active (MBEA, 4 items) that "focuses on monitoring task execution for any problems that might arise and correcting those problems to maintain current performance levels" (Avolio et al., 1999, p. 445). We did not include 
management by exception-passive (MBEP), because prior analysis has shown that MBEP does not correlate with either contingent rewards or MBEA but instead correlates highly with laissezfaire leadership, which refers to the absence of leadership behavior (Avolio et al., 1999). Thus MBEP is more frequently grouped with laissez-faire to indicate a third leadership style, passiveavoidant (Avolio et al., 1999; Derue et al., 2011).

We subsequently dropped contingent rewards from our measure of transactional leadership though. Empirically, there was a high correlation between contingent rewards and transformational leadership in our data $(\mathrm{r}=.82)$. This high correlation was consistent with prior research. In a meta-analysis of leadership literature, Derue et al. (2011) calculate an average correlation of .80 between contingent rewards and transformational leadership. Other studies (e.g., Avolio et al., 1999; Lowe et al., 1996) have found similarly high correlations, in the neighborhood of .70-.80. From a conceptual point of view, prior research (e.g., Avolio et al., 1999; Shamir, 1995; Vera and Crossan, 2004) has discussed the conceptual overlap between transformational and transactional leadership, particularly with regard to contingent rewards. For example, Shamir (1995) notes that with behaviors emphasizing contingent rewards, leaders build trust and dependability, which contributes to the high levels of trust and respect associated with transformational leadership. Similarly, Derue et al. (2011) note conceptual overlap between transformational leadership and behaviors for initiating structure, such as specifying expectations and rewards (i.e., contingent rewards). Consequently, we only included MBEA as the measure for transactional leadership. This measure is highly reliable, with a Cronbach's alpha of .87.

Stakeholder-oriented marketing. We derived the measure for stakeholder-oriented marketing from relevant literature on contemporary marketing practices (e.g., Brookes and Palmer, 2004; Coviello et al., 2002) and stakeholder orientation (Ferrell et al., 2011). 
Stakeholder-oriented marketing requires that marketing activities go beyond a narrow customer focus to include all relevant stakeholders, such as suppliers, service providers, and local communities. Firms practicing stakeholder-oriented marketing also commit substantial resources to cultivate networks of relationships in the wider marketing system and often involve senior management and cross-functional teams to carry out their marketing activities. Nine items were used to measure the degree to which a firm practices stakeholder-oriented marketing. The measure is highly reliable, with a Cronbach's alpha of .91.

Institutional CSR practices. In line with prior literature (e.g., Godfrey et al., 2009; Mattingly and Berman, 2006), we only included CSR activities targeting community and environment to measure institutional CSR practices. To derive the exact measurement items, we reviewed prior literature (Maignan et al., 1999; Turker, 2009) and conducted in-depth interviews with managers. This exploratory research resulted in a list of 12 items to measure institutional CSR. The measure for institutional CSR is highly reliable, with a Cronbach's alpha of .95 . Organizational outcomes. The measure for organizational outcomes came from prior literature (Brown and Dacin, 1997; Fombrun and Shanley, 1990; Freeman, 1984; Menon and Menon, 1997; Sen and Bhattacharya, 2001; Turban and Greening, 1997). We measured organizational outcomes as performance relative to expectations, rather than absolute performance, because prior research has shown that respondents not only find it easier but also are more willing to report relative performance, particularly with regard to intangible outcomes (Coviello et al., 2002; Parasuraman et al., 1994). Four items captured a firm's performance with regard to stakeholder relationship, corporate reputation, and visibility. Prior CSR literature has suggested that CSR practices have positive impacts on these organizational outcomes (Du et al., 
2007; Fombrun and Shanley, 1990; Handelman and Arnold, 1999). The measure is reliable $($ Cronbach's alpha $=.80)$.

Control variables. Our control variables included organizational type (business-tobusiness vs. business-to-consumer) and organizational size. We controlled for organizational type because research suggests that, relative to business-to-business firms, business-to-consumer firms are more likely to use CSR to build a favorable image and provide psychological benefits (i.e., identification; Drumwright, 1994; McWilliams and Siegel, 2001; Sen and Bhattacharya, 2001). Therefore, all else being equal, we expect that business-to-consumer firms engage in institutional CSR to a greater extent. We controlled for size, because research suggests that size plays a role in determining the level of a firm's CSR commitment (McWilliams and Siegel, 2001). For example, according to the resource-based view, larger firms can better afford resources to spend on institutional CSR practices and are more likely to reap benefits from institutional CSR practices (Godfrey et al., 2009).

We dummy coded these two organizational demographic variables to include them as covariates in the regression analyses. The orgtype variable equaled 1 if the organization was primarily in business-to-consumer markets, and 0 otherwise. The orgsize variable was defined by a median split of the number of people employed, equal to 1 if the organization employed more than 100 people and 0 otherwise.

Common method bias. Because we relied on a single source for our measures, common method bias in self-reported measures could be a concern. Employing the widely used Harman's one-factor method (e.g., Carr and Kaynak, 2007; Podsakoff and Organ, 1986), we ran a factor analysis of all measures to examine the likelihood of a single or dominant factor. The unrotated solution showed no evidence of a dominant common factor (seven factors had eigenvalues 
greater than 1.0; the first factor accounted for only $19 \%$ of the total variance). Thus, common method bias did not seem to represent a serious issue for this study. Furthermore, prior research shows that interaction effects cannot be artifacts of common method bias; on the contrary, common method bias makes it more difficult to detect interaction effects (Siemsen et al., 2010). Therefore, at a minimum, common method bias is unlikely to account for the results relating to $\mathrm{H} 2$ and $\mathrm{H} 3$, which deal with interaction effects.

\section{Results}

We tested our hypotheses using multiple regressions with relevant interaction terms. To enhance the interpretation of the regression coefficients in moderated regression models, we mean-centered all continuous independent variables (Aiken and West, 1991). Table I contains the means, standard deviations, and reliability coefficients of the key variables, as well as correlations among them.

\section{Insert Table I about Here}

We tested $\mathrm{H} 1$ and $\mathrm{H} 2$ using a moderated regression model: institutional $\mathrm{CSR}=f$ (transformational leadership, transactional leadership, stakeholder-oriented marketing, transformational leadership $\times$ stakeholder-oriented marketing, transactional leadership $\times$ stakeholder-oriented marketing, orgtype, orgsize). Table II lists the estimation results.

\section{Insert Table II about Here}

In $\mathrm{H} 1$ we predicted that transformational (but not transactional) leadership is positively associated with institutional CSR. As expected, the coefficient for transformational leadership is 
positive and significant $(b=.90, p<.01)$, whereas the coefficient for transactional leadership is not significant $(\mathrm{b}=-.01, \mathrm{NS})$, in support of $\mathrm{H} 1$.

Also as expected, the coefficient for stakeholder-oriented marketing is positive and significant $(b=.29, p<.01)$, so stakeholder-oriented marketing relates positively to institutional CSR practices. Furthermore, in line with $\mathrm{H} 2$, we find a positive interaction between stakeholderoriented marketing and transformational leadership $(b=.16, p<.01)$, indicating that stakeholderoriented marketing amplifies the positive link between transformational leadership and institutional CSR practices. To clarify the nature of this interaction, we performed a simple slope analysis (Aiken and West, 1991) by looking at the transformational leadership-institutional CSR link when the moderator variable, stakeholder-oriented marketing, was one standard deviation above and below the mean. With high stakeholder-oriented marketing (i.e., one standard deviation above the mean), the coefficient for the simple slope of transformational leadership on institutional CSR practices is $\mathrm{b}=1.06(\mathrm{t}=10.54, p<.01)$. With low stakeholder-oriented marketing (i.e., one standard deviation below the mean), the coefficient for the simple slope of transformational leadership on institutional CSR practices is $\mathrm{b}=.76(\mathrm{t}=9.05, p<.01)$. These results suggest that the relationship between transformational leadership and institutional CSR practices is stronger when stakeholder-oriented marketing is high and significantly weaker when stakeholder-oriented marketing is low. Therefore, $\mathrm{H} 2$ is supported by our data.

Finally, $\mathrm{H} 3$ examines the moderating role of transactional leadership in the relationship between institutional CSR and organizational outcomes. To test H3, we ran a moderated regression: organizational outcomes $=f$ (institutional CSR practices, transformational leadership, transactional leadership, transformational leadership $\times$ institutional CSR practices, transactional leadership $\times$ institutional CSR practices, stakeholder-oriented marketing, orgtype, orgsize). 
Stakeholder-oriented marketing is included as a covariate in this model, because research suggests that it relates positively to organizational outcomes (Bhattacharya and Korschun, 2008; Lindgreen et al., 2009). The estimation results are in Table III.

Insert Table III about Here

In line with leadership literature, we find that transformational leadership is positively associated with organizational outcomes $(\mathrm{b}=.15, p<.01)$, whereas transactional leadership is not $(b=.04, \mathrm{NS})$. Stakeholder-oriented marketing is positively associated with organizational outcomes $(\mathrm{b}=.15, p<.01)$. In line with $\mathrm{H} 3$, we find that institutional CSR practices not only have a positive main effect $(b=.14, p<.01)$ on organizational outcomes but that this positive link is greater with higher transactional leadership (i.e., positive interaction between institutional CSR practices and transactional leadership: $\mathrm{b}=.05, p<.05)$. Simple slope analysis indicates that, with transformational leadership at the mean level, when transactional leadership is high (i.e., one standard deviation above the mean), the simple slope of institutional CSR practices on organizational outcomes is $\mathrm{b}=.19(\mathrm{t}=5.35, p<.01)$. Also with transformational leadership being at the mean level, when transactional leadership is low (i.e., one standard deviation below the mean), the simple slope of institutional CSR practices on organizational outcome is $b=.09(\mathrm{t}$ $=2.57, p<.05)$. These results suggest that, all else being equal, transactional leadership amplifies the positive relationship between institutional CSR practices and organizational outcomes, in support of $\mathrm{H} 3$.

We also notice a negative interaction between institutional CSR practices and transformational leadership $(b=-.04, p<.10)$, indicating that transformational leadership reduces the positive relationship between institutional CSR practices and organizational 
outcomes. Simple slope analysis indicates that, with transactional leadership at the mean level, when transformational leadership is high (one standard deviation above the mean), the simple slope of institutional CSR practices on organizational outcomes is $\mathrm{b}=.10(\mathrm{t}=2.80, p<.01)$. With transactional leadership at the mean level, when transformational leadership is low (i.e., one standard deviation below the mean), the simple slope of institutional CSR practices on organizational outcomes is $\mathrm{b}=.18(\mathrm{t}=5.04, p<.01)$. These results in turn suggest that, all else being equal, transformational leadership diminishes the positive relationship between institutional CSR practices and organizational outcomes.

\section{Discussion}

Despite the prominent place CSR has on the global corporate agenda, our understanding of micro-level organizational dynamics about CSR, such as the interface between leadership styles and CSR, remains incipient (Angus-Leppan et al., 2009; Groves and LaRocca, 2011b). This study has sought to shed light on the ways in which transformational and transactional leadership styles affect a firm's institutional CSR practices, as well as the organizational outcomes of CSR. Specifically, we develop and test a theoretical framework pertaining to (1) how transformational (but not transactional) leadership affects institutional CSR practices, (2) how stakeholder-oriented marketing influences the transformational leadership-institutional CSR link, and (3) how leadership styles influence the relationship between institutional CSR and organizational outcomes.

Through a large-scale field survey of managers, we find that firms with greater transformational leadership are more likely to engage in institutional CSR practices, but transactional leadership is not associated with these CSR practices. Furthermore, stakeholderoriented marketing reinforces the positive link between transformational leadership and 
institutional CSR practices. Finally, our results show that transactional leadership enhances, whereas transformational leadership diminishes, the positive relationship between institutional CSR practices and organizational outcomes. Our research highlights the differential roles that transformational and transactional leadership styles play in a firm's institutional CSR practices, which have significant implications for theory and practice.

\section{Theoretical implications}

Although much has been said about the salubrious effects of CSR on stakeholder support, loyalty, and retention (e.g., Bhattacharya et al., 2008), less is known about the driving effects of the leadership styles displayed by managers on a firm's CSR policies and outcomes (AngusLeppan et al., 2009; Groves and LaRocca, 2011b; Waldman et al., 2006). This study has provided much needed empirical evidence concerning the differential roles of transformational and transactional leadership styles in the firm's institutional CSR practices. Our findings have implications for theories of CSR and leadership.

By documenting the positive association between transformational leadership and institutional CSR, this study advances knowledge about organizational drivers of CSR. Although prior research has conceptualized various organizational antecedents to CSR, such as managers' mental frames and sense-making processes (Basu and Palazzo, 2008), organizational culture (e.g., future or performance orientations; Berger et al., 2007), and leadership styles (Angus-Leppan et al., 2009), large-scale empirical studies of organizational drivers of CSR are lacking (cf. Waldman et al., 2006). This research bridges leadership literature and CSR literature to provide empirical evidence on the transformational leadership-institutional CSR link. Specifically, this study places transformational leadership in the context of stakeholder theory (Bass and Steidlmeier, 1999; Pless and Maak, 2011) and shows that transformational leaders are likely to 
exhibit responsible leadership by, among others, promoting institutional CSR that advances the welfare of secondary stakeholders. Furthermore, integrating theoretical constructs from organizational behavior and marketing, we find that the link between transformational leadership and institutional CSR is not constant across all firms but instead depends on the level of stakeholder-oriented marketing practiced by the firm. This result attests to the importance of taking a cross-disciplinary approach in CSR research (Du et al., 2011; Raghubir et al., 2010). Specifically, to fully unleash the potential of transformational leadership in promoting socially responsible business practices, complementary organizational capabilities such as stakeholderoriented marketing are essential. This result documents, for the first time, the complementarity between a firm's leadership capabilities and marketing capabilities in driving its CSR practices. Research on organizational antecedents to CSR should continue to adopt a broad theoretical perspective that spans different business disciplines (e.g., organizational behavior, marketing, strategy, information system).

By documenting, for the first time, the moderating role of leadership styles in the organizational outcomes of CSR, this research extends prior literature on the business case of CSR. Our findings are particularly interesting in light of prior research on leadership. Specifically, prior literature has consistently found high correlations between transformational leadership and a range of effectiveness criteria, such as follower job satisfaction, percentage of goals met, and financial performance of the work unit; in contrast, transactional leadership appears less effective (Bass et al., 2003; Derue et al., 2011; Lowe et al., 1996). However, we find that transactional leadership amplifies, whereas transformational leadership diminishes, the positive link between institutional CSR and organizational outcomes. This finding accentuates the unique strength of transactional leadership in deriving business benefits from institutional 
CSR and suggests that, in certain circumstances, transactional leadership is effective but transformational leadership is not.

The dampening effect of transformational leadership on the organizational outcomes of CSR indicates that this leadership style is not without peril; by itself, it seems to detract from CSR's ability to create value for the firm. This unexpected finding extends prior literature, which mostly documents positive effects of transformational leadership.

\section{Practical implications}

This study highlights the importance of organizational leadership in a firm's CSR endeavors. Despite the well-accepted belief that CSR is critical to firms' ability to meet their stakeholder obligations and obtain sustained growth (Lindgreen and Swaen, 2009), many firms struggle to promote socially responsible business practices and maximize the social and business returns to their CSR (Kotler and Lee, 2005; Porter and Kramer, 2006). Our findings suggest that leadership styles play an essential role. Specifically, a transformational leadership style is best suited for initiating and designing socially responsible practices; transactional leadership is best suited for implementing and deriving business benefits from socially responsible practices. Since a "win-win" situation, by satisfying the business motives of the firm while also ensuring sustained corporate investment in CSR, feeds into a "circle of virtue," it appears that both transformational and transactional leadership styles are required for successful institutional CSR practices. Our findings thus suggest that managers should adopt a pluralistic approach to leadership and practice transformational leadership in conjunction with transactional leadership. This recommendation is consistent with Quinn's (1988) concept of a "master manager," who chooses transformational or transactional behaviors depending on the circumstances. In particular, transactional leadership behaviors, by managing the mundane, day-to-day events (e.g., 
monitoring, corrective actions, continuous improvement), augment transformational leadership behaviors. Collectively, both styles serve to reinforce a firm's CSR endeavors.

This study also suggests that firms should attend to the supporting role of marketing to provide the appropriate organizational context for CSR practices (Lindgreen et al., 2009). A firm's stakeholders are embedded in interconnected networks of relationships, through which the firm's marketing actions reverberate with both direct and indirect consequences (Bhattacharya and Korschun, 2008). Stakeholder-oriented marketing practices encourage organizational members to care about the welfare of all stakeholders and devise creative solutions that address stakeholder issues. Our findings confirm that by practicing stakeholder-oriented marketing, a firm can cultivate an organizational climate conducive to CSR practices. Furthermore, stakeholder-oriented marketing provides the essential cross-functional support for transformational leadership in a firm's efforts to promote CSR practices. Transformational leaders should mindfully build and leverage complementary capabilities (e.g., stakeholderoriented marketing) that facilitate their socially responsible actions.

\section{Limitations and further research}

Several caveats should be taken into consideration when interpreting the results of this study. First, the cross-sectional design limits the degree to which we can make causal inferences and test the strength of the relationships over time. Replications and extensions of our findings using experimental and longitudinal designs are needed. Second, we employ a single-informant technique (i.e., one respondent from each firm) and measure all variables with a common method (i.e., field survey). Although our analysis indicates that common method bias is not a serious issue, additional research should employ multi-informant and multimethod designs to overcome this potential limitation. Third, this study involves only U.S. firms. Further research should 
examine the generalizability of our findings in countries with different cultures (e.g., individualistic vs. collectivistic) or different economic developmental stages (e.g., developing countries). Fourth, we only use MBEA as the measure of transactional leadership. Research should examine the role of another component of transactional leadership, contingent rewards, in a firm's CSR practices. More generally, further work on how other dimensions of leadership, beyond transformational and transactional, influence CSR policies and success would help deepen understanding of this important but underexamined internal driver of CSR.

\section{References}

Aiken, L.S. and S.G. West: 1991, Multiple Regression: Testing and Interpreting Interactions (Newbury Park, CA: Sage).

Angus-Leppan, T., L. Metcalf, and S. Benn: 2009, 'Leadership styles and CSR practice: An examination of sensemaking, institutional drivers and CSR leadership', Journal of Business Ethics 93, 189-213.

Avolio, B.J., B.M. Bass, and D.I. Jung: 1999, 'Re-examining the components of transformational and transactional leadership using the multifactor leadership questionnaire', Journal of Occupational and Organizational Psychology 72, 441-62.

Bass, B.M.: 1985, Leadership and Performance Beyond Expectations (New York: Academic Press).

Bass, B.M.: 1997, 'Does the transactional-transformational leadership paradigm transcend organizational and national borders?' American Psychologist 52, 130-139.

Bass, B.M.: 1998, Transformational Leadership: Industrial, Military, and Educational Impact (Mahwah, NJ: Lawrence Erlbaum Associates). 
Bass, B.M. and B.J. Avolio: 1993, 'Transformational leadership and organizational culture', Public Administration Quarterly 17, 112-121.

Bass, B.M. and B.J. Avolio: 2000, MLQ: Multifactor Leadership Questionnaire, 2nd ed. (Redwood City, CA: Mind Garden).

Bass, B.M., B.J. Avolio, D.I. Jung, and Y. Berson: 2003, 'Predicting unit performance by assessing transformational and transactional leadership', Journal of Applied Psychology 88, 207-218.

Bass, B.M. and P. Steidlmeier: 1999, 'Ethics, character, and authentic transformational leadership behaviour', Leadership Quarterly 10, 181-217.

Basu, K. and G. Palazzo: 2008, 'Corporate social responsibility: A process model of sensemaking', Academy of Management Review 33, 122-136.

Berger, I.E., P. Cunningham, and M.E. Drumwright: 2007, 'Mainstreaming corporate social responsibility: Developing markets for virtue', California Management Review 49, 132-157.

Bhattacharya, C.B. and D. Korschun: 2008, 'Stakeholder marketing: Beyond the four P's and the customer', Journal of Public Policy \& Marketing 27, 113-116.

Bhattacharya, C.B., D. Korschun, and S. Sen: 2008, 'Strengthening stakeholder-company relationships through mutually beneficial corporate social responsibility initiatives', Journal of Business Ethics 85, 257-272.

Bono, J.E. and T.A. Judge: 2003, 'Self-concordance at work: Toward understanding the motivational effects of transformational leaders', Academy of Management Journal 46, 554571.

Brookes, R. and R. Palmer: 2004, The New Global Marketing Reality (London: Palgrave). 
Brown, T.J. and P.A. Dacin: 1997, 'The company and the product: Corporate associations and consumer product responses', Journal of Marketing 61, 68-84.

Burns, J.M.G.: 1978, Leadership (New York: Harper and Row).

Campbell, J.L.: 2007, 'Why would corporations behave in socially responsible ways? An institutional theory of corporate social responsibility', Academy of Management Review 32, 946-967.

Carr, A. and H. Kaynak: 2007, 'Communication methods, information sharing, supplier development and performance', International Journal of Operations and Production Management 27, 346-370.

CorporatePhilanthropy: 2011, 'Giving in numbers: trends in corporate giving', available at: http://www.corporatephilanthropy.org/measurement/benchmarking-reports/giving-innumbers.html. Accessed December 21, 2011.

Coviello, N.E., R.J. Brodie, P.J. Danaher, and W.J. Johnston: 2002, 'How firms relate to their markets: an empirical examination of contemporary marketing practices', Journal of Marketing 66, 33-46.

Derue, D.S., J.D. Nahrgang, N. Wellman, and S.E. Humphrey: 2011, ‘Trait and behavioral theories of leadership: an integration and meta-analytic test of their relative validity', Personnel Psychology 64, 7-52.

Drumwright, M.E.: 1994, 'Socially responsible organizational buying: environmental concern as a noneconomic buying criterion', Journal of Marketing 58, 1-19.

Du, S., C.B. Bhattacharya, and S. Sen: 2007, 'Reaping relational rewards from corporate social responsibility: The role of competitive positioning', International Journal of Research in Marketing 24, 224-241. 
Du, S., C.B. Bhattacharya, and S. Sen: 2011, 'Corporate social responsibility and competitive advantage: Overcoming the trust barrier', Management Science 57, 1528-1545.

Du, S., S. Sen, and C.B. Bhattacharya: 2008, 'Exploring the social and business returns of a corporate oral health initiative aimed at disadvantaged Hispanic families', Journal of Consumer Research 35, 483-494.

Ferrell, O.C., T.L. Gonzalez-Padron, G.T.M. Hult, and I. Maignan: 2010, 'From market orientation to stakeholder orientation', Journal of Public Policy \& Marketing 29, 93-96.

Fombrun, C. and M. Shanley: 1990, 'What's in a name? Reputation building and corporate strategy', Academy of Management Journal 33, 233-258.

Freeman, R.E.: 1984, Strategic Management: A Stakeholder Approach (Boston, MA: Pitman Publishing).

Freeman, R.E., J.S. Harrison, and A.C. Wicks: 2007, Managing for Stakeholders: Business in the 21st Century (New Haven, CT: Yale University Press).

Friedman, M.: 1970, 'The social responsibility of business is to increase its profit', The New York Times Magazine, 13 September: 32-33, 122, 124, 126.

Godfrey, P.C., C.B. Merrill, and J.M. Hansen: 2009, 'The relationship between corporate social responsibility and shareholder value: An empirical test of the risk management hypothesis', Strategic Management Journal 30, 425-445.

Groves, K.S. and M.A. LaRocca: 2011a, 'Responsible leadership outcomes via stakeholder CSR values: Testing a values-centered model of transformational leadership', Journal of Business Ethics 98, 37-55. 
Groves, K.S. and M.A. LaRocca: 2011b, 'An empirical study of leader ethical values, transformational and transactional leadership, and follower attitudes toward corporate social responsibility', Journal of Business Ethics 103, 511-528.

Handelman, J.M. and S.J. Arnold: 1999, 'The role of marketing actions with a social dimension: Appeals to the institutional environment', Journal of Marketing 63, 33-48.

Hart, S.: 1997, 'Beyond greening: Strategies for a sustainable world', Harvard Business Review 75, 66-76.

Hoffman, A.J. and M.H. Bazerman: 2007, 'Changing practice on sustainability: Understanding and overcoming the organizational and psychological barriers to action', in S. Sharma, M. Starik, and B. Husted (eds.), Organizations and the Sustainability Mosaic: Crafting LongTerm Ecological and Societal Solutions (Northampton, MA: Edward Elgar).

Kotler, P. and N. Lee: 2005, Corporate Social Responsibility: Doing the Most Good for Your Company and Your Cause (Hoboken, NJ: Wiley \& Sons).

Lindgreen, A. and V. Swaen: 2009, 'Corporate social responsibility', International Journal of Management Reviews 12, 1-7.

Lindgreen, A., V. Swaen, and W. Johnston: 2009, 'The supporting function of marketing in corporate social responsibility', Corporate Reputation Review 12, 120-139.

Lowe, K.B., K.G. Kroeck, and N. Sivasubramaniam: 1996, 'Effectiveness correlates of transformational and transactional leadership: a meta-analytic review of the MLD literature', Leadership Quarterly 7, 385-425.

Luo, X. and C.B. Bhattacharya: 2006, 'Corporate social responsibility, customer satisfaction, and market value', Journal of Marketing 70, 1-18. 
Luo, X. and C.B. Bhattacharya: 2009, 'The debate over doing good: Corporate social performance, strategic marketing levers, and firm-idiosyncratic risk', Journal of Marketing 73, 198-213.

Maak, T. and N.M. Pless: 2006, 'Responsible leadership in a stakeholder society—A relational perspective', Journal of Business Ethics 66, 99-115.

Maignan, I., O.C. Ferrell, and G. Hult: 1999, 'Corporate citizenship: cultural antecedents and business benefits', Journal of the Academy of Marketing Science 27, 455-469.

March, J.: 1991, 'Exploration and exploitation in organizational learning', Organizational Science 2, 71-87.

Margolis, J.D. and J.P. Walsh: 2003, 'Misery loves companies: Rethinking social initiatives by business', Administrative Science Quarterly 48, 268-305.

Mattingly, J.E. and S. Berman: 2006, 'Measurement of corporate social action: discovering taxonomy in the Kinder Lydenburg Domini ratings data', Business and Society 45, 20-46.

McWilliams, A. and D. Siegel: 2001, 'Corporate social responsibility: A theory of the firm perspective', Academy of Management Review 26, 117-127.

Mendonca, M.: 2001, 'Preparing for ethical leadership in organizations', Canadian Journal of Administrative Sciences 18, 266-276.

Menon, A. and A. Menon: 1997, 'Enviropreneurial marketing strategy: The emergence of corporate environmentalism as marketing strategy', Journal of Marketing 61, 51-67.

Mitchell, R.K., B.R. Agle, and D.J. Wood: 1997, 'Toward a theory of stakeholder identification and salience: Defining the principle of who and what really counts', Academy of Management Review 22, 853-886. 
Palazzo, G. and A.G. Scherer: 2006, 'Corporate legitimacy as deliberation: A communicative framework', Journal of Business Ethics 66, 71-88.

Parasuraman, A., V. Zeithaml, and L. Berry: 1994, 'Reassessment of expectations as a comparison standard in measuring service quality: implications for further research', Journal of Marketing 58(January), 111-124.

Pfeffer, J. and G. Salancik: 1978, The External Control of Organizations (New York: Harper \& Row).

Pless, N.M. and T. Maak: 2011, 'Responsible leadership: pathways to the future', Journal of Business Ethics 98, 3-13.

Podsakoff, P.M. and D.W. Organ: 1986, 'Self-reports in organizational research: Problems and prospects', Journal of Management 12, 531-44.

Porter, M.E. and M.R. Kramer: 2006, 'Strategy and society: The link between competitive advantage and corporate social responsibility', Harvard Business Review 84, 78-92.

Porter, M.E. and M.R. Kramer: 2011, 'Creating shared value', Harvard Business Review 89, 6277.

Quinn, R.E.: 1988, Beyond Rational Management: Mastering the Paradoxes and Competing Demands of High Performance (San Francisco, CA: Jossey-Bass).

Raghubir, P., J. Roberts, K. Lemon, and R. Winer: 2010, 'Why, when, and how should the effect of marketing be measured? A stakeholder perspective for corporate social responsibility metrics', Journal of Public Policy \& Marketing 29, 66-77.

Scott, W.R.: 1987, 'The adolescence of institutional theory', Administrative Science Quarterly $32,493-511$. 
Sen, S. and C.B. Bhattacharya: 2001, 'Does doing good always lead to doing better? Consumer reactions to corporate social responsibility', Journal of Marketing Research 38, 225-243.

Shamir, B.: 1995, 'Social distance and charisma: Theoretical notes and an exploratory study', Leadership Quarterly 6, 19-47.

Siemsen, E., A. Roth, and P. Oliveira: 2010, 'Common method bias in regression models with linear, quadratic, and interactional effects', Organizational Research Methods 13(3), 456476.

Stieglitz, N. and K. Heine: 2007, 'Innovation and the role of complementarities in a strategic theory of the firm', Strategic Management Journal 28, 1-15.

Teece, D.J., G. Pisano, and A. Shuen: 1997, 'Dynamic capabilities and strategic management', Strategic Management Journal 18, 509-533.

Turban, D.B. and D.W. Greening: 1997, 'Corporate social performance and organizational attractiveness to prospective employees', Academy of Management Journal 40, 658-672.

Turker, D.: 2009, 'How corporate social responsibility influences organizational commitment', Journal of Business Ethics 89, 189-204.

Vera, D. and M. Crossan: 2004, 'Strategic leadership and organizational learning', Academy of Management Review 29, 222-240.

Waddock, S.: 2004, 'Parallel universes: companies, academics, and the progress of corporate citizenship', Business and Society Review 109, 5-42.

Waddock, S: 2008, Leading Corporate Citizens: Vision, Values, and Value Added, 3rd ed. (New York: McGraw-Hill/Irwin).

Waldman, D.A., B.M. Bass, and W.O. Einstein: 1987, 'Leadership and outcomes of performance appraisal processes', Journal of Occupational Psychology 60, 177-186. 
Waldman, D.A. and D.S. Siegel: 2008, 'Defining the socially responsible leader', Leadership Quarterly 19, 117-131.

Waldman, D.A., D.S. Siegel, and M. Javidan: 2006, 'Components of CEO transformational leadership and corporate social responsibility', Journal of Management Studies 43, 17031725.

Walumbwa, F.O., B.J. Avolio, and W. Zhu: 2008, 'How transformational leadership weaves its influence on individual job performance: the role of identification and efficacy beliefs', Personnel Psychology 61, 793-825.

Yoon, Y., Z. Gurhan-Canli, and N. Schwarz: 2006, 'The effect of corporate social responsibility: CSR) activities on companies with bad reputations', Journal of Consumer Psychology 16, 377-390.

Yukl, G.: 1999, 'An evaluation of conceptual weaknesses in transformational and charismatic leadership theories', Leadership Quarterly 10, 285-305. 


\section{Appendix: Measurement Instrument}

Transformational leadership (IS = intellectual stimulation, $C H I=$ charisma/inspiration $)$

In our firm, managers... (5-point scale, 1 = "never," 5 = "frequently, if not always")

1) re-examine critical assumptions to question whether these are appropriate (IS)

2) seek differing perspectives when solving problems (IS)

3) get others to look at problems from many different angles (IS)

4) suggest new ways of looking at how to complete assignments (IS)

5) talk about their most important values and beliefs (CHI)

6) specify the importance of having a strong sense of purpose (CHI)

7) consider the moral and ethical consequences of decisions (CHI)

8) emphasize the importance of having a collective sense of mission (CHI)

9) talk optimistically about the future (CHI)

10) talk enthusiastically about what needs to be accomplished (CHI)

11) articulate a compelling vision of the future (CHI)

12) express confidence that goals will be achieved $(\mathrm{CHI})$

13) instill pride in others for being associated with them (CHI)

14) go beyond self-interest for the good of the group (CHI)

$15)$ act in ways that build others' respect for me (CHI)

16) display a sense of power and confidence (CHI)

Transactional leadership $(M B E A=$ management by exception-active, $C R=$ contingent reward $)$

In our firm, managers... (5-point scale, 1 = "never," 5 = "frequently, if not always")

1) focus attention on irregularities, mistakes, exceptions, and deviations from standards (MBEA)

2) concentrate their full attention on dealing with mistakes, complaints, and failures (MBEA)

3) keep track of all mistakes (MBEA)

4) direct their attention towards failure to meet standard (MBEA)

5) provide others with assistance in exchange for their efforts (CR)

6) discuss in specific terms who is responsible for achieving performance targets (CR)

7) make clear what one can expect to receive when performance goals are achieved (CR)

8) express satisfaction when others meet expectations (CR)

\section{Institutional CSR Practices}

Our firm systematically attempts to... (7-point scale, 1 = "strongly disagree," 5 = "strongly agree")

1) incorporate the interests of the communities where we operate in our business decisions

2) financially support education in the communities where we operate

3) stimulate the economic development in the communities where we operate

4) help improve the quality of life in the communities where we operate

5) give money to charities in the communities where we operate

6) financially support activities (arts, culture, sports) in the communities where we operate

7) voluntarily exceed government-imposed environmental regulations

8) incorporate environmental concerns in our business decisions

9) incorporate environmental performance objectives in our organizational plans

10) financially support environmental initiatives

11) measure our organization's environmental performance

12) minimize the environmental impact of all our firm's activities 


\section{Stakeholder-oriented marketing practices}

(5-point scale, 1 = "never," 5 = "always")

1) Our marketing activities are intended to coordinate activities between ourselves, customers, and other parties in our wider marketing system (e.g., key suppliers, service providers, and other firms with which we interact through our marketing activities).

2) Our marketing planning is focused on issues related to the network of relationships between individuals and organizations in our wider marketing system

3) When dealing with our market(s), our purpose is to form relationships with a number of firms in our market(s) or the wider marketing system

4) Our firm's contact with our primary customers is from impersonal to interpersonal (e.g., involving one-to-one interaction between people) across firms in the broader network

5) The type of relationship with our primary customers is characterized as contact with people in our organization and the wider marketing system that is ongoing

6) Our marketing resources (i.e., people, time, and money) are invested in developing our firm's network relationships within our market(s) or the wider marketing system

7) Our marketing communication involves senior managers networking with other managers from a variety of firms in our market(s) or the wider marketing system

8) When people from our firm meet with our primary customers it is at both a formal business level and informal social level in a wider organizational system / network

9) Overall, our firm's general approach to our primary customers involves positioning our organization in a wider organizational system / network

\section{Organizational outcomes}

This year, how has your firm performed relative to expectations for... (5-point scale, $1=$ "much worse," 5 = "much better")

1) improving relations with environment (e.g., people in the community)

2) improving relations with stakeholders in general

3) improving corporate image / reputation

4) gaining national and international visibility 
TABLE I

Descriptive statistics and correlations

\begin{tabular}{llllllll}
\hline \multicolumn{1}{c}{ Variable } & Mean & SD & 1 & 2 & 3 & 4 & 5 \\
\hline 1. Transformational leadership & 3.68 & .86 & .96 & & & & \\
2. Transactional leadership & 3.05 & .99 & .27 & .87 & & & \\
3. Stakeholder-oriented marketing & 3.33 & .95 & .46 & .28 & .91 & & \\
4. Institutional CSR & 4.67 & 1.43 & .60 & .19 & .44 & .95 & \\
5. Organizational outcomes & 3.45 & .75 & .42 & .19 & .39 & .48 & .80 \\
\hline
\end{tabular}

Notes: $\mathrm{n}=440$. Reliability coefficients are reported on the diagonal. All correlations are significant at $p<.01$. 


\section{TABLE II}

Antecedents of institutional CSR: unstandardized regression coefficients

\begin{tabular}{ll}
\hline & Institutional CSR \\
\hline Stakeholder-oriented marketing & $.28^{* *}$ \\
Transformational leadership & $.91^{* *}$ \\
Transactional leadership & -.01 \\
Transformational leadership $\times$ stakeholder-oriented & $.16^{* *}$ \\
marketing & \\
Transactional leadership $\times$ stakeholder-oriented marketing & -.02 \\
Organizational type & $.18^{+}$ \\
Size & $.29^{* *}$ \\
Adjusted $\mathrm{R}^{2}$ & .41 \\
F value & $43.99^{* *}$ \\
\hline
\end{tabular}

${ }^{* *} p<.01,{ }^{*} p<.05,{ }^{+} p<.10$. 


\section{TABLE III}

Organizational outcomes of institutional CSR: unstandardized regression coefficients

\begin{tabular}{ll}
\hline & Organizational outcomes \\
\hline Institutional CSR & $.14^{* *}$ \\
Transformational leadership & $.15^{* *}$ \\
Transactional leadership & .04 \\
Institutional CSR x transformational leadership & $-.04^{+}$ \\
Institutional CSR x transactional leadership & $.05^{*}$ \\
Stakeholder-oriented marketing & $.15^{* *}$ \\
Organizational type & $.18^{* *}$ \\
Size & $.14^{*}$ \\
& \\
Adjusted $\mathrm{R}^{2}$ & .32 \\
$\mathrm{~F}$ & $22.88^{* *}$ \\
\hline
\end{tabular}

${ }^{* *} p<.01,{ }^{*} p<.05,{ }^{+} p<.10$. 
Figure 1. Conceptual framework

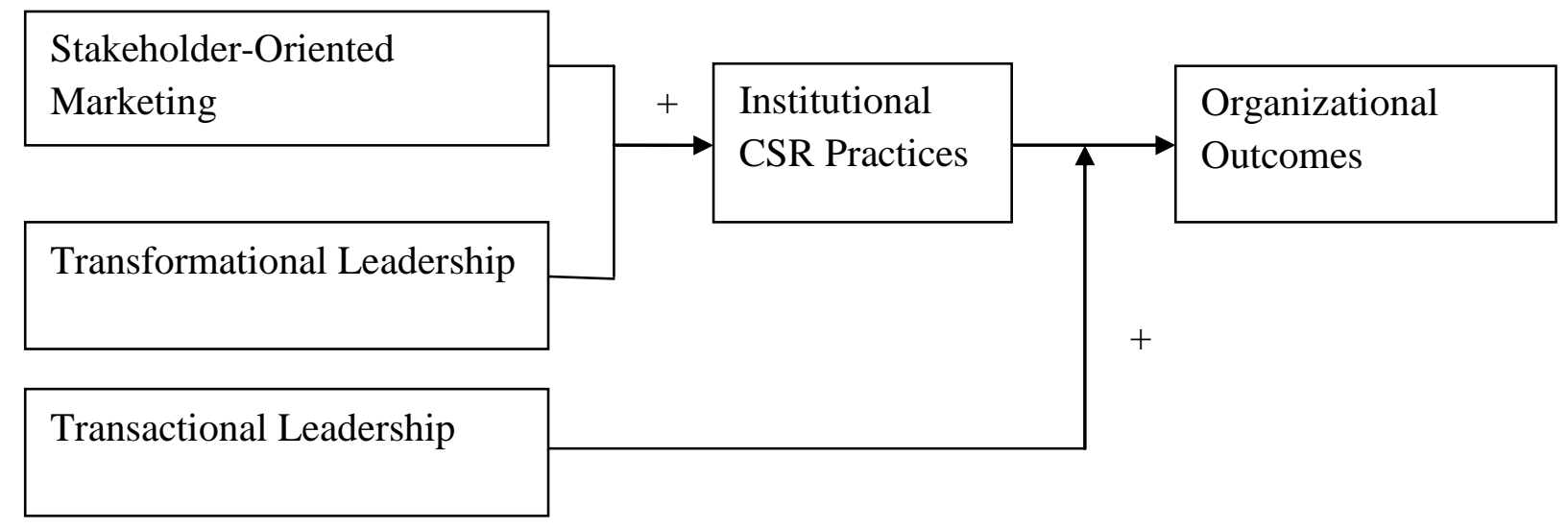

